\title{
The Golden Ratio and Michelangelo's Influence in Gaspar Becerra`s Flayed Man
}

\author{
Deivis de Campos, ${ }^{1,2,3}$ Luciano Buso, ${ }^{4}$ Pamela Brambilla Bagatini,, ${ }^{5}$ Dauana loara Prass, ${ }^{2}$ Léder Leal Xavier ${ }^{5}$ \\ 'Departamento de Ciências Básicas da Saúde, Universidade Federal de Ciências da Saúde de Porto Alegre, Porto Alegre, RS, Brazil. \\ 2Departamento de Ciências da Vida, Universidade de Santa Cruz do Sul, Santa Cruz do Sul, RS, Brazil \\ ${ }^{3}$ Programa de Pós-Graduação em Promoção da Saúde, Universidade de Santa Cruz do Sul, Santa Cruz do Sul, RS, Brazil \\ ${ }^{4}$ Treviso, 31030, San Vito di Altivole, Italy, Studioso e ricercatore scientifico nel campo dell'arte \\ 5Laboratório de Biologia Celular e Tecidual, Departamento de Ciências Morfofisiológicas, Faculdade de Biociências, Pontifícia Universidade \\ Católica do Rio Grande do Sul, Porto Alegre, RS, Brazil.
}

Disclose and conflicts of interest: none to be declared by all authors

\section{ABSTRACT}

Introduction: This manuscript presents an unprecedented hypothesis that the Flayed Man [Taoula. I. del Lib. II] by Gaspar Becerra (1520-1570), published in the classic study on the Historia de la composicion del cuerpo humano (1556) by Juan Valverde de Amusco (ca.1525-1587), may have been elaborated according to a mathematical relation known since antiquity as the Golden Ratio (GR) (1.6), which is identified in the organization of numerous biological structures, in both the animal and plant kingdoms.

Materials and methods: To test this hypothesis, we used Image Pro Plus Software 6.0 [Media Cybernetics, Silver Spring, MD, USA] to measure the distances between critical elements within the Taoula. I. del Lib. II.

Results: The way in which the GR is presented in the Flayed Man by Gaspar Becerra, uniquely resembles the pattern previously used by Michelangelo Buonarroti (1475-1564) in the figure of Saint Bartholomew, painted in the fresco of the Last Judgment (1536-1541) in the Sistine Chapel in Rome, Italy.

Conclusion: Currently there is no known description attributed to Michelangelo himself regarding the use of the GR in his art. Nevertheless, the present study provides evidence to show Michelangelo may have personally instructed Gaspar Becerra regarding the foundations of the GR and the ways in which it might be applied in works of art.

Key words: Flayed Man; Gaspar Becerra; Golden Ratio; Michelangelo; Saint Bartholomew.

\section{Introduction}

The specialized literature has shown that the Spanish painter and sculptor, Gaspar Becerra (15201570) illustrated one of the most famous works in the area of human anatomy entitled Historia de la composicion del cuerpo humano, by Juan Valverde de Amusco (ca.1525-1587) that was first published in Rome, Italy (1556) $\cdot^{1-4}$ Among the various engravings made by Gaspar Becerra for this book, that referred to as Taoula. I. del Lib. II is particularly noteworthy. This engraving shows a Flayed Man, holding his skin in the right hand and a flaying knife in the left hand (Figure 1). ${ }^{2-4}$ Based on the striking similarities between the figures in the two works, some authors argue that Gaspar Becerra's Flayed Man (Taoula. I. del Lib. II) was inspired by Michelangelo's painting of Saint Bartholomew in the Last Judgment fresco (1536-1541) which is located on the wall behind the altar of the Sistine Chapel in Rome, Italy (Figure 1) ${ }^{1,2,5}$

However, the similarities between the two figures go beyond the anatomical features. As will be demonstrated in this manuscript, Gaspar Becerra may have elaborated the image of Flayed Man in accordance with the mathematical relation, widely known as the Golden Ratio (GR) (1.6), which had also been applied in the image of Saint Bartholomew by Michelangelo Buonarroti (1475-1564). ${ }^{6}$

\section{The Golden Ratio}

The mathematical relationship known as the Golden Ratio (GR) (1.6) is the ratio between two lines of unequal length, where the ratio between the length of the shorter line and the longer line is the same as the ratio between length of the longer line and the sum of the lengths, as follows: $b / a=(a+b) / b=1.6$ (Figure 2). ${ }^{6-9}$ Since its discovery, probably by Euclid of Alexandria around $300 \mathrm{BC}$, the GR has been identified in the organization of numerous biological structures, in both the animal and plant kingdoms. ${ }^{9-11}$ The GR is classically associated with greater structural efficiency and has puzzled scientists for centuries due to its frequent occurrence in nature. ${ }^{6,7,10,12,13}$ Moreover, the GR is not only found in natural/biological phenomena, it has also been incorporated into countless works of art, , ,14 including some Michelangelo's most famous works. ${ }^{6,712}$ 


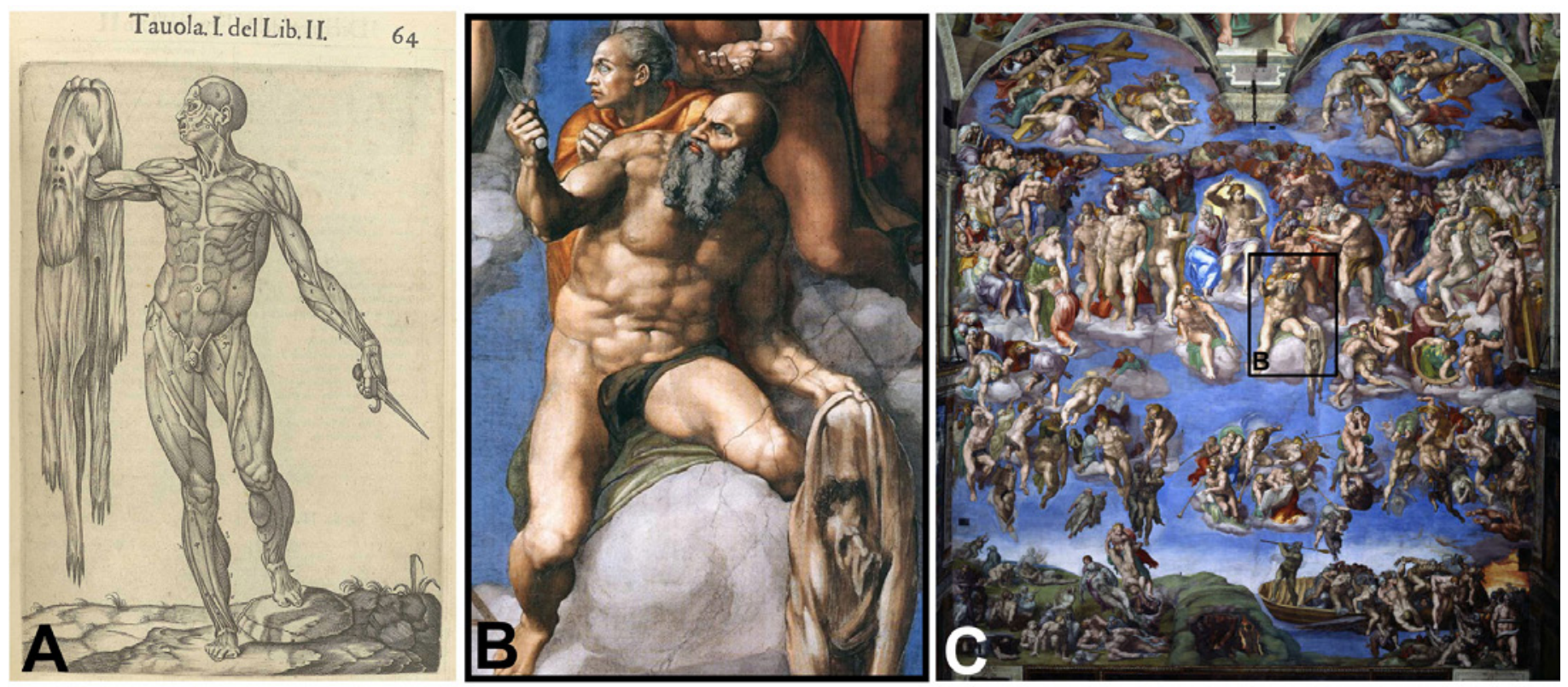

Figure 1. (A) Gaspar Becerra's engraving of the Flayed Man [Taoula. I. del Lib. II] in the Historia de la composicion del cuerpo humano (1556), by Juan Valverde de Amusco. Note the similarity between Gaspar Becerra's Flayed Man and Saint Bartholomew (B) in the fresco the Last Judgment (C) [14m x 13.18m], elaborated by Michelangelo Buonarroti (1475-1564) between 1536 and 1541 (Sistine Chapel, Vatican, Rome, Italy).

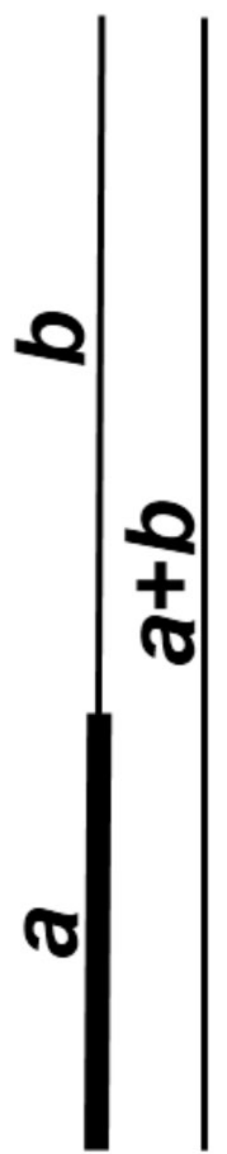

\section{$b / a=(a+b) / b=1.6$}

Figure 2. The Golden Ratio (1.6) is a proportion of lengths of line segments, where the ratio between the lengths of the longer and shorter lines is equal to that of the ratio between the combined lengths of the two lines and the length of the longer line (Modified from De Campos et al, 2015').

\section{Materials and Methods}

A recent study reveals that the point of the flaying knife held by Saint Bartholomew in Michelangelo's fresco of the Last Judgment in the Sistine Chapel, marks the point at which the fresco can be spatially divided according to the GR (Figure 3). ${ }^{6}$ Hence, it may be the case the point of the flaying knife in Gaspar Becerra's image of the Flayed Man (Taoula. I. del Lib. II), might also be the point used to define the GR in this image, since there is great similarity between the two images., ${ }^{1,25}$ To test this hypothesis, we used Image Pro Plus Software 6.0 [Media Cybernetics, Silver Spring, $\mathrm{MD}, \mathrm{USA}]$ to measure the distances between critical elements within the Taoula. I. del Lib. II, and extract the same proportions of line segments used to obtain GR, as shown in Figure 2. Using the actual dimensions of the Taoula. I. del Lib. II $[30 \mathrm{~cm} \times 20 \mathrm{~cm}]^{4}$ and in accordance with the rules established for obtaining the GR, ${ }^{6-8}$ it is apparent that if the vertical line $[a+b]$ is divided into two unequal portions at the point of the flaying knife held by the Flayed Man, the ratio of the larger segment $[b]$ to the smaller $[a]$ is equal to the ratio of $[a+b]$ to $[b]$, thus obtaining exactly 1.6 (Figure 4 ).

\section{Discussion}

Historically, the GR is seen as the most pleasing aesthetic proportion to the eye. Moreover, many art experts suggest the aesthetic quality of any work of art may be influenced by its compatibility with the GR. ${ }^{6-9,15}$ For these experts, the GR is the key to understanding all the proportions in the most refined forms of art and nature. ${ }^{9}$

Within this context, this manuscript provides strong evidence to show one of the most recognized images 

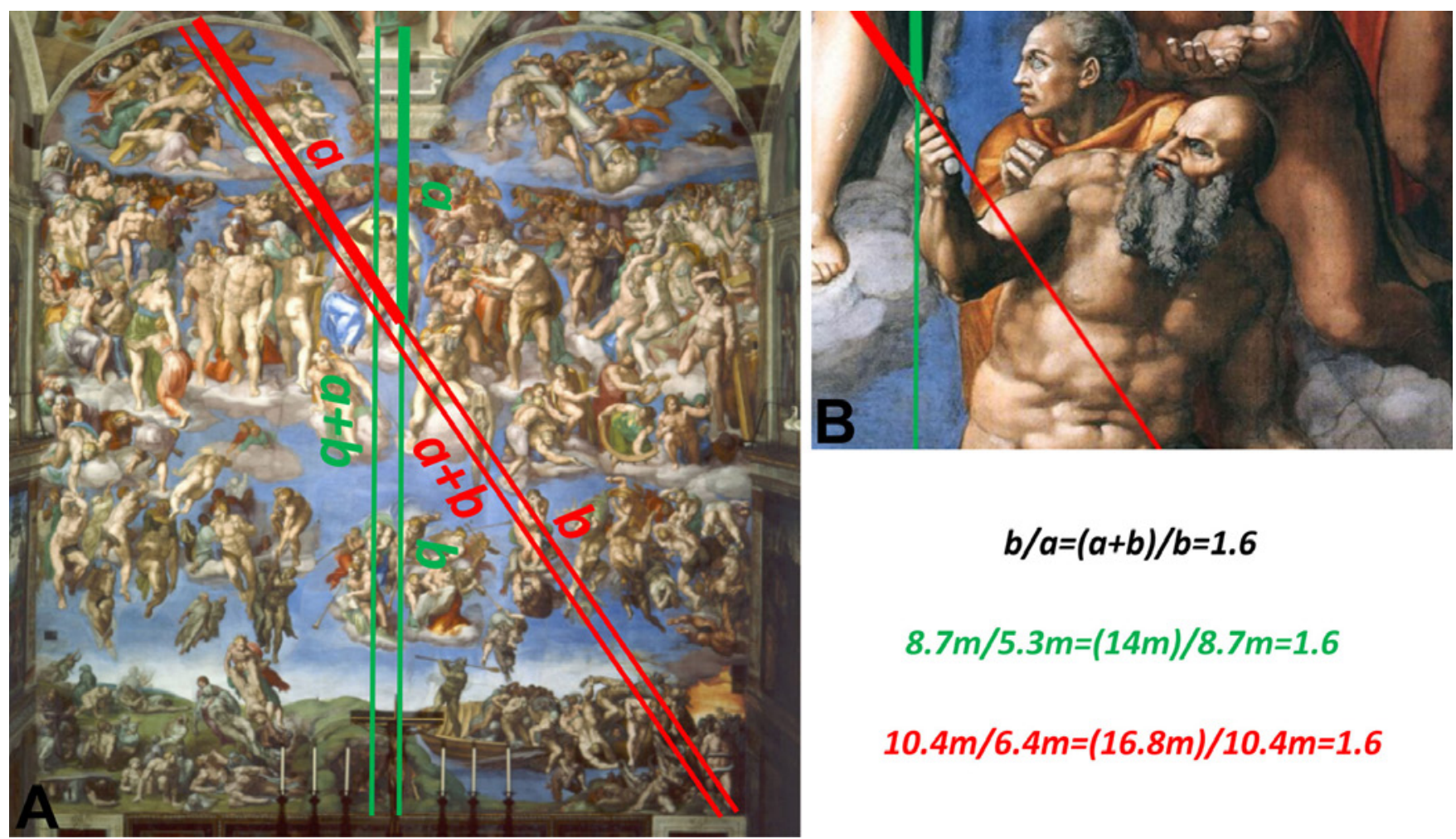

\section{$b / a=(a+b) / b=1.6$}

\section{$8.7 m / 5.3 m=(14 m) / 8.7 m=1.6$}

\section{$10.4 m / 6.4 m=(16.8 m) / 10.4 m=1.6$}

Figure 3. The Last Judgement fresco (A) and, in detail, Saint Bartholomew (B) with your flaying knife lying exactly on the line segment that forms the Golden Ratio (1.6) [vertical (green lines) and diagonal (red lines) position] (Modified from De Campos et al, 20156). Michelangelo Buonarroti (1536-1541), Sistine Chapel, Vatican, Rome.
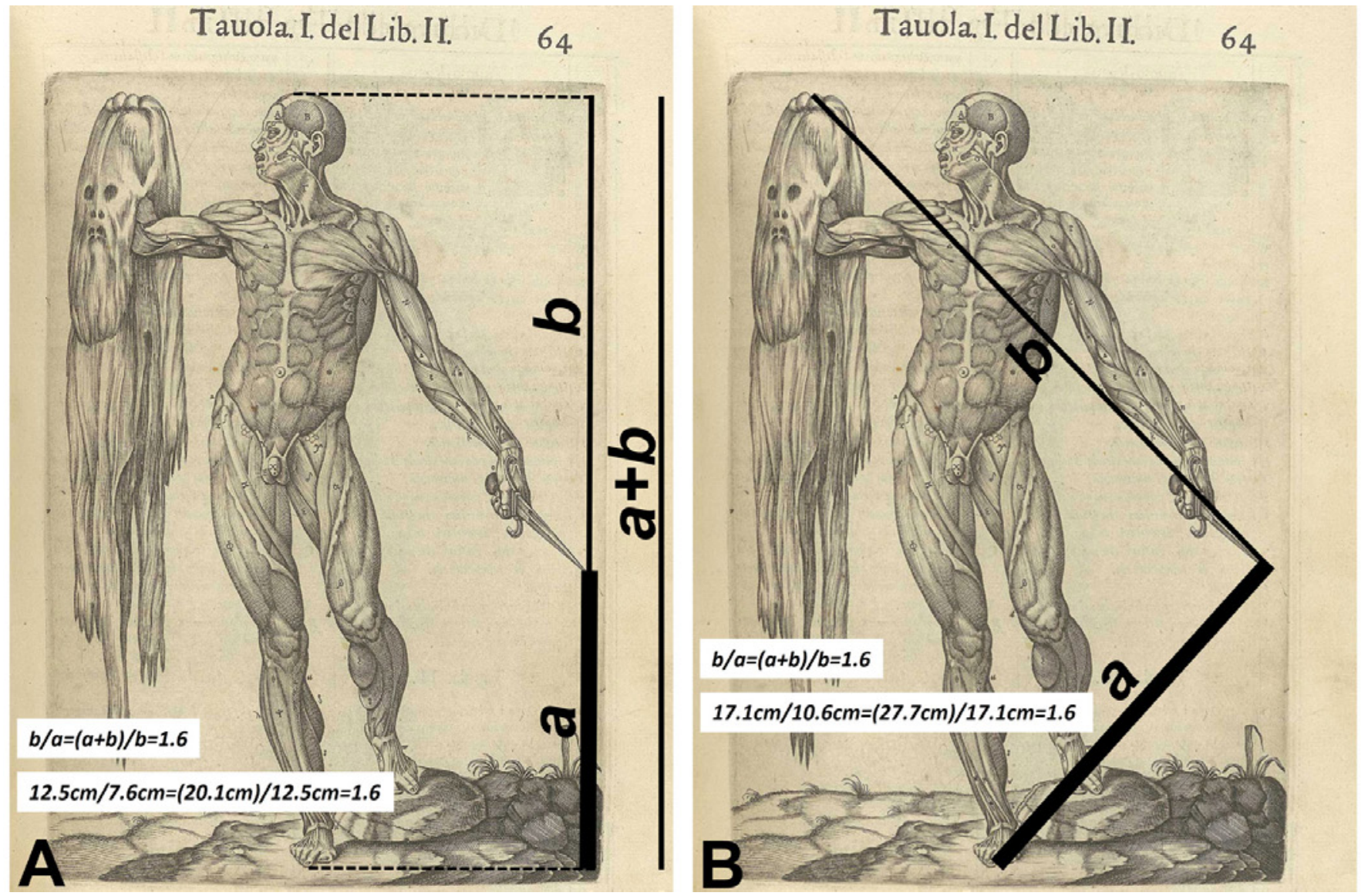

Figure 4. (A) Note that in Gaspar Becerra's engraving $[30 \mathrm{~cm} \times 20 \mathrm{~cm}]$, the tip of the flaying knife is located precisely at the intersection of the line segments that form the Golden Ratio (1.6) according to the full height of the Flayed Man. (B) Note that the length of a line from the top of the right hand to the tip of the flaying knife, divided by the length of a line from that same point to the base of the right foot also gives the Golden Ratio. All measurements were taken with the aid of Image Pro Plus Software 6.0; Media Cybernetics, Silver Spring, MD, USA. To calibrate the Image Pro Plus Software, the following commands were used: Measure/Calibration/Spatial. 
among the classical studies of the human anatomy, the Flayed Man, may have been elaborated according to the principles of the GR. However, the GR as observed in Gaspar Becerra's Flayed Man, appears to differ from the standards commonly used by the Renaissance artists. In many works/paintings from the Renaissance period the GR is only found in the total dimensions of the work [in the ratio between the height and the width $=1.6]$, without any relation to the characters or critical elements composing them. ${ }^{9}$

The manner in which the GR is formed by the position of the point of the flaying knife in Gaspar Becerra's Flayed Man, is similar to that used by Michelangelo in the Last Judgment. ${ }^{6}$ In this context, recent studies ${ }^{6,7}$ indicate that Michelangelo may have discretely positioned some critical elements/specific points within the fresco so that they would serve as the dividing line in the formation of the GR.

Before dying, Michelangelo burnt a large number of drawings and annotations for various works, ${ }^{16,17}$ which undoubtedly makes it difficult to reach any conclusion regarding this subject. Not even in Michelangelo's biography, written by Giorgio Vasari (1511-1574) in 1550 , which is a primordial historical document on the artist's life and work, ${ }^{18}$ is there any mention of the use of GR in Michelangelo's works or the guidance he provided to his pupils. Nevertheless, the absence of evidence does not imply evidence of absence, and Michelangelo's particular way of using the GR may have been passed directly to Gaspar Becerra.

Although Gaspar Becerra's name is not among those included in the classic literature describing Michelangelo's life and work, there are references in the specialized literature to indicate Gaspar Becerra studied for many years in Michelangelo's studio., ${ }^{3,17-21}$

In addition, both are known to have dissected many cadavers to better understand human anatomy., ${ }^{3,16,19,22,23}$ The knowledge gained from those dissections certainly contributed to ensuring the representations of the human body in their works of art would be much closer to reality ${ }^{16}$ For this reason, many Renaissance artists, including Michelangelo, practiced dissection and studied human cadavers. ${ }^{16,22-27}$

Interestingly, it is reported that in the period in which Michelangelo painted the Last Judgment (1536-1541), he resumed practicing dissection intensely, because he was intending to produce a treatise on anatomy with the renowned anatomist Realdo Colombo (15161559), the purpose of which would be contrasted with the purely quantitative approach to the human body of the painter and mathematician Albrecht Dürer (14711528), who was, according to Michelangelo himself, unable to capture the atti and gesesti umani [human acts and gestures]. ${ }^{17}$ Unsurprisingly, it is precisely in the Last Judgment that Michelangelo manages to combine his knowledge of human anatomy with the acts and gestures of his characters. In this fresco, Michelangelo, besides improving the representation of the muscular anatomy of his characters, also gives them a great variety of movements, gestures and expressions. ${ }^{16}$

During Gaspar Becerra's apprenticeship with Michelangelo, he would have learned many of his master's skills and techniques, including those used in the Last Judgment. ${ }^{19,28}$ As shown by a drawing by Gaspar Becerra (Museo del Prado in Madrid, Spain) (Figure 5), some parts of the Michelangelo's Last Judgment were even copied by Becerra, although those copies would have been of Michelangelo's original drawings, since they do not seem to correspond to the completed fresco. ${ }^{19}$ This demonstrates Gaspar Becerra's great interest in Michelangelo's fresco of the Last Judgment, and obviously in all the techniques used in its elaboration, including those related to the GR.

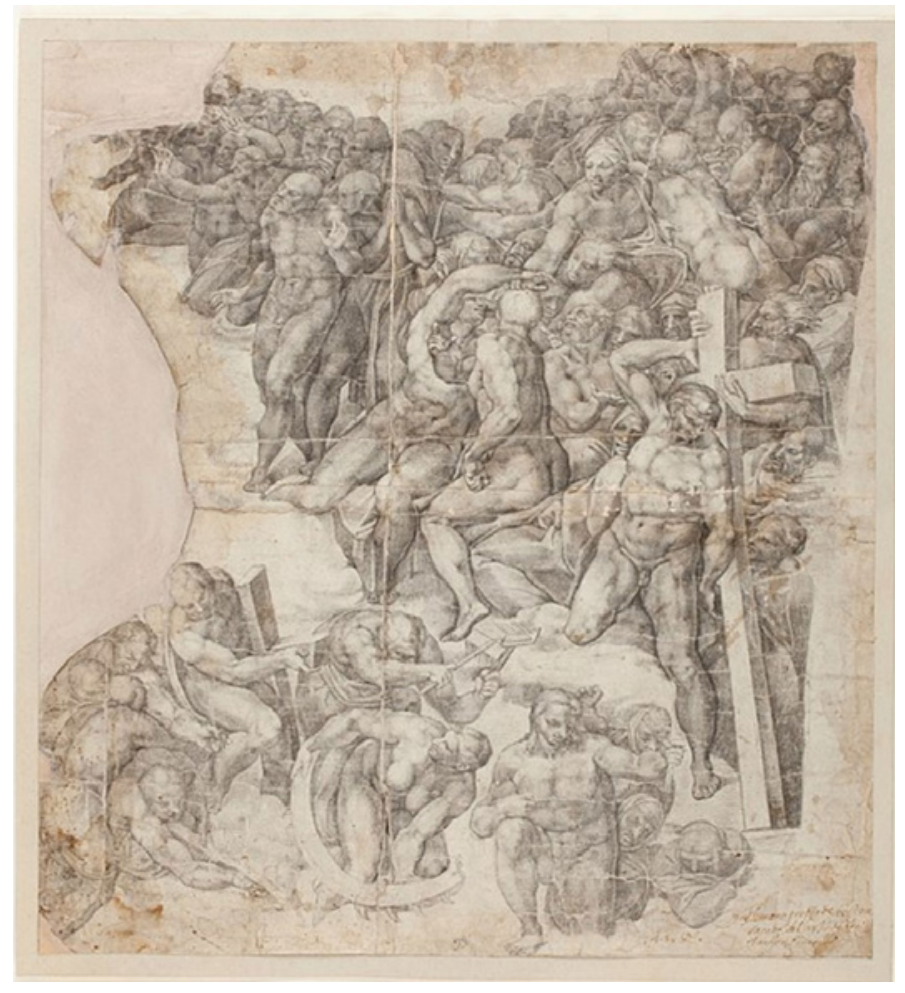

Figure 5. Partial copy of Michelangelo's Last Judgment [400mm x 365mm - Black chalk on yellow paper], made by Gaspar Becerra in the XVI century (Museo del Prado, Madrid, Spain).

It would therefore be plausible to suppose that Michelangelo, in addition to having provided copies of his original drawings for the Last Judgment to Gaspar Becerra to study and even copy, he may also have passed on knowledge about the use of the GR in art, especially concerning the importance that the flaying knife held in Saint Bartholomew hand could 
play in forming the GR in the final version of the Last Judgment in the Sistine chapel.

Thus, the resemblance between Gaspar Becerra's representation of the Flayed Man and Michelangelo's Saint Bartholomew may not be merely anatomical. Both may have been elaborated in accordance with a mathematical relation (GR), which appears, almost supernaturally, throughout nature and, which for most experts, represents a model of perfect proportion that ensures more agreeable aesthetic qualities.

"The senses delight in things duly proportioned." St. Thomas Aquinas (ca.1225-1274)

\section{References}

1. Barreto G, Oliveira MG. A arte secreta de Michelangelo: uma lição de anatomia na Capela Sistina. São Paulo: ARX; 2004.

2. Eknoyan G. Michelangelo: art, anatomy, and the kidney. Kidney Int 2000; 57:1190-1201.

3. Laurenza D. Art and Anatomy in Renaissance Italy: Images from a Scientific Revolution. New York: Metropolitan Museum of Art; 2012.

4. Valverde de Amusco J. Historia de la composicion del cuerpo humano. Valladolid: Editorial Maxtor Librería; 2005.

5. Stimilli D. The Face of Immortality: Physiognomy and Criticism. New York: State University of New York Press; 2005.

6. De Campos D, Malysz T, Bonatto-Costa JA, Pereira Jotz G, Pinto De Oliveira Junior L, Oxley da Rocha A. Michelangelo, the Last Judgment fresco, Saint Bartholomew and the Golden Ratio. Clin Anat 2015; 28:967-971.

7. De Campos D, Malysz T, Bonatto-Costa JA, Pereira Jotz G, Pinto De Oliveira Junior L, Oxley da Rocha A. More than a neuroanatomical representation in The Creation of Adam by Michelangelo Buonarroti, a representation of the Golden Ratio. Clin Anat 2015; 28:702-705.

8. Hutchison AL, Hutchison RL. Fibonacci, Littler, and the Hand: A Brief Review. Hand 2010; 5:364-368.

9. Livio M. The Golden Ratio: The Story of Phi, The World's Most Astonishing Number. New York: Broadway Books; 2002.

10. De Campos D. Degree of myelination (g-Ratio), Divine proportion and Fibonacci sequence - A mathematical relationship. J Anat Soc India 2014; 63:s44-s45.

11. Liu Y, Sumpter DJT. Is the golden ratio a universal constant for self-replication? PLoS One 2018; 13:e0200601.

12. De Campos D, Da Costa Oliveira M. Michelangelo Buonarroti's code in the frescoes of the Sistine Chapel - an allusion to Gematria of the Hebrew/Greek alphabet and the Golden Ratio. Clin Anat 2018; 31:948-955.

13. Yalta K, Ozturk S, Yetkin E. Golden Ratio and the heart: A review of divine aesthetics. Int J Cardiol 2016; 214:107-112.

14. Green CD. All that glitters: A review of psychological research on the aesthetics of the golden section. Perception 1995; 24:937-968.

15. McManus IC, Weatherby P. The Golden Section and the aesthetics of form and composition: A cognitive model. Empirical Studies of the Arts 1997; 15:209-232.

16. Blech B, Doliner R. The Sistine Secrets: Michelangelo's Forbidden Messages in the Heart of the Vatican. New York: HarperCollins Publishers; 2008.

17. Vasari G. Vida de Michelangelo Buonarroti: florentino, pintor, escultor e arquiteto (1568) / Giorgio Vasari; tradução, introdução e comentário: Luiz Marques. Campinas: Editora da Unicamp; 2011. 18. Vasari G. The Lives of the Artists. Oxford: Oxford University Press Inc; 1991.

19. Ames-Lewis F, Joannides P. Reactions to the Master: Michelangelo's Effect on Art and Artists in the Sixteenth Century. Burlington: Ashgate Publishing; 2003.

20. Gayford M. Michelangelo: His Epic Life. London: Penguin Books Ltd; 2013.

21. Longo LD, Reynolds LP. Wombs with a View: Illustrations of the Gravid Uterus from the Renaissance through the Nineteenth Century. New York: Springer International Publishing; 2016.

22. Ellwanger JH, Mohr H, Campos D. Anatomy lessons in the Michelangelo's works? J Morphol Sci 2012; 29:38-43.

23. Santos IP, Rosa JPC, Ellwanger JH, Molz P, Rosa HT, Campos D. Michelangelo's art on the Sistine Chapel ceiling: sacred representation or anatomy lessons? J Morphol Sci 2013; 30:1-6.

24. De Campos D. A hidden rib found in Michelangelo Buonarroti's fresco The Creation of Adam. Clin Anat 2019; 32:648-653.

25. De Campos D, Malysz T, Bonatto-Costa JA, et al. The hidden symbols of the female anatomy in Michelangelo Buonarroti's ceiling in the Sistine Chapel. Clin Anat 2016; 29:911-916.

26. De Campos D, Oxley Da Rocha A, De Oliveira Lemos R, et al. Pagan symbols associated with the female anatomy in the Medici Chapel by Michelangelo Buonarroti. Clin Anat 2017; 30:572-577.

27. Lydiatt DD, Bucher GS. Historical vignettes of the thyroid gland. Clin Anat 2011; 24:1-9.

28. Dillon A. Michelangelo and the English Martyrs. New York: Ashgate Publishing; 2012.
Received: April 4, 2018

Accepted: July 7, 2019
Corresponding author

Deivis de Campos

dcampos@ufcspa.edu.br 